\title{
CHANGES IN EMPHASIS AND PRESENT USAGE OF CERTAIN PERSONNEL MANAGEMENT PRACTICES IN 109 PUBLIC INSTITUTIONS*
}

\author{
R. VERSTER \\ DEPARTMENT OF INDUSTRIAL PSYCHOLOGY \\ UNIVERSITY OF BOPHUTHATSWANA
}

\begin{abstract}
OPSOMMING
Baie min empiriese navorsing oor die status van personeelbestuur in die openbare sektor in Suid-Afrika is tot op hede onderneem. In hierdie opname-tipe ondersoek is ingegaan op die mate waarin klemverskuiwings na of van sekere personeelfunksies plaasgevind het asook op die huidige gebruik van sekere algemene personeelpraktyke sowel as in diensnemings-, opleiding en ontwikkelings-, vergoedingsverhoudings-, kontrole- en navorsingspraktyke. Die resultate van groot en klein openbare instellings is afsonderlik ontleed. Die resultate dui op verskeie areas in personeelbestuur in openbare instellings waarop verbeter kan word.
\end{abstract}

During the past 11 years the Personnel Research Division of the University of the O.F.S. has investigated amongst other things, the status of various personnel management functions in South African industry. Most of these investigations were survey-type investigations and therefore suffer from the inherent limitations and shortcomings of questionnaire research. On the other hand, these research projects uncovered information on the status of personnel management in South Africa in general and on various personnel functions in particular, which was and still is not available from other sources. If the potential user of these research findings constantly bears in mind what the scope and limitations of the findings are, this research could serve a useful purpose to both industry and universities.

In many of the investigations by the Personnel Research Division a classification of private and public sectors was used. Very often the numbers of public institutions which participated were rather small. This and other considerations have sparked off the idea of

\footnotetext{
* Requests for reprints should be sent to the author.
} 
conducting a separate investigation into the status of personnel management in the public sector (cf Verster, 1980).

\section{METHOD}

A four page questionnaire was used in this investigation. Apart from the total staff establishment, information was requested on aspects such as:

- $\quad$ changes in the environment in which personnel management is practised;

- the structure of the personnel management function; staffing the personnel department/ division;

- $\quad$ opinions on the professionalisation of personnel management;

- $\quad$ breakdown of personnel resources devoted to different personnel management functions;

- changes in emphasis to or from a variety of personnel management functions; and the present usage of a large number of personnel management practices.

The public institutions in South Africa as classified by Cloete (1978), was used as mailing list for the 250 questionnaires dispatched. One hundred and twenty questionnaires were received back. At the request of the then Public Service Commission, the questionnaires received from government departments were omitted from the analyses. This was done due to the process of rationalisation in the Public Service. One hundred and nine questionnaires were used in the final analyses.

One can, therefore, not claim full representativeness with regard to the entire public sector. One particular section of the public sector, namely local authorities, participated satisfactorily $-51,7 \%$ (105 506 employees) of the total staff establishment of local authorities, was represented in this investigation (Department of Labour, 1979, p. 299).

According to the kind of public institution, the sample can be described as follows: 
Local authorities 60

Public corporations

Provincial administrations

Bantu Affairs Administration Boards $\quad 8$

Universities /technikons

$\begin{array}{ll}\text { Service organisations } & 2\end{array}$

$\begin{array}{ll}\text { Divisional councils } & 3\end{array}$

$\begin{array}{ll}\text { Agricultural produce control boards } & 5\end{array}$

Other public institutions mainly at provincial level $\underline{9}$

The total staff establishment of these 109 participating public institutions was 379357 .

It is suggested that the status of personnel management within a particular organisation is influenced by the size of the organisation. For example, one expects assessment centres, a separate training division and techniques of similar sophistication to be used more often in larger than in smaller organisations.

In this article therefore, apart from the results of the total sample, the results of small and large public institutions are also compared. For this purpose the participating public institutions whose total staff establishment was smaller or equal to the sample staff establishment median $(\mathrm{Me}=791)$ were regarded as small, whereas those exceeding the median value were considered to be large.

Three public institutions have not answered the two sections of the questionnaire used in this article in detail and were therefore omitted from the analyses. The number of participants for the purpose of this article was therefore reduced to $106(n=106)$. 


\section{Changes in emphasis ${ }^{*}$ to or from personnel management functions}

Respondents were asked to indicate on a five point scale the extent to which the emphasis has shifted during the past three years to or from a number of personnel management functions in their organisation. The scale ranged from increased considerably, increased, remained the same, decreased to decreased considerably. A scale value was given to each answer (increased considerably $=1$ to decreased considerably $=5$ ).

A mean scale value was computed for each function. A mean scale value of 1 thus indicates a large shift in emphasis towards the specific personnel management function. The results are shown in Table 1.

TABLE 1

CHANGES IN EMPHASIS TO OR FROM PERSONNEL MANAGEMENT FUNCTIONS DURING THE PAST THREE YEARS (MEAN SCALE VALUES)

\begin{tabular}{|c|c|c|c|}
\hline & 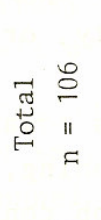 & 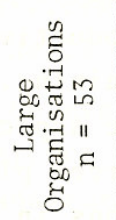 & 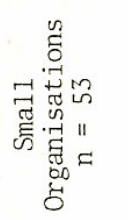 \\
\hline Organisational and job design & 2,19 & 2,15 & 2,25 \\
\hline Industrial relations & 2,52 & 2,33 & $2,72 *$ \\
\hline Intercultural relations in the job context & 2,64 & 2,50 & $2,77 * *$ \\
\hline Upgrading of Non-white employees & 2,07 & 1,89 & $2,25 *$ \\
\hline Organisational development & 2,32 & 2,24 & 2,40 \\
\hline Preparing management for change & 2,45 & 2,26 & $2,64 *$ \\
\hline Management development & 2,34 & 2,13 & $2,55 *$ \\
\hline Identification of managerial potential & 2,56 & 2,52 & 2,60 \\
\hline Identification of promotion potential & 2,47 & 2,35 & $2,59 * *$ \\
\hline Improving productivity & 2,14 & 2,07 & 2,21 \\
\hline Development of personnel management systems & 2,43 & 2,20 & $2,66 *$ \\
\hline Career planning & 2,76 & 2,67 & 2,85 \\
\hline Integration of military servicemen & 2,63 & 2,50 & $2,76 * *$ \\
\hline Systematising the compensation system & 2,36 & 2,24 & 2,47 \\
\hline Employee training & 2,25 & 2,04 & $2,47 *$ \\
\hline Scientific selection of personnel & 2,47 & 2,26 & $2,68 *$ \\
\hline Manpower planning & 2,56 & 2,43 & $2,70 * *$ \\
\hline Personnel research & 2,72 & 2,59 & $2,85 * *$ \\
\hline
\end{tabular}

\footnotetext{
* No operational definition of "emphasis" was provided in the questionnaire but it was taken that the amount of personnel resources in terms of time, manpower and personnel management budget devoted to the particular personnel management function, determined the importance and emphasis. The preceding question in the questionnaire dealt with the issue of personnel resources devoted to personnel management functions and therefore served as an explanation of what was meant by "emphasis".
} 
From Table 1 the following are amongst other things evident:

- $\quad$ In the sample as a whole

- $\quad$ the largest shift in emphasis during the past 3 years towards personnel management functions has occurred with regard to the upgrading of Non-white employees, improving productivity, organisational and job design and employee training.

- the aspects towards which the emphasis changed least are career planning, personnel research, intercultural relations in job context, integration of military servicemen, manpower planning and identification of managerial potential.

- In the total sample as well as in large and small public institutions, the emphasis has shifted more with regard to management development than to identification of managerial potential. It would be a better strategy to devote more effort to the identification of potential first, before embarking on management development. One might argue that the initial effort to identify was considered adequate. Yet, when one looks at some personnel practices which could be used to determine managerial and supervisory potential, that is psychological tests for managerial and supervisory personnel and assessment centres for selection and training purposes (see Tables 2a and $2 \mathrm{~b}$ ), you find that these practices are, in the majority of public institutions, not being used at all (it ranges from $63 \%$ to $74 \%$ ).

- The emphasis has shifted significantly more in large than in small public institutions with regard to several personnel management functions viz. industrial relations, upgrading of Non-white employees, preparing management for change, management development, development of personnel management systems, employee training, scientific selection of personnel (all on the $1 \%$ level), intercultural relations, identification of promotion potential, integration of military servicemen, manpower planning and personnel research (all at the $5 \%$ level).

These changes in emphasis should, however, not be evaluated in isolation but should always be viewed in conjunction with the extent of usage of the related personnel management practices as shown in Tables 2(a to f) since emphasis towards a function may not be related to the application of personnel practices. 
Extent of present usage of personnel management practices

Respondents were requested to indicate whether they use a number of personnel management practices fully, partly or not at all. The results, expressed as percentages, are shown in Tables 2(a to f).

From Table 2(a) the following are amongst other things evident:

- $\quad$ In the total sample

- $\quad$ organisational planning and job design is in most cases only partly used.

- job enrichment/enlargement and integrated personnel systems are in most public institutions not being used at all (49, $1 \%$ and 38,7\% respectively).

- Assessment centres for various purposes are seldom being used.

TABEL 2(a)

EXTENT OF USAGE OF ORGANISATIONAL AND JOB DEȘIGN PRACTICES

AND ASSESSMENT CENTRES

(Percentages)

\begin{tabular}{|c|c|c|c|c|c|c|}
\hline & \multicolumn{3}{|c|}{$\begin{array}{c}\text { TOTAL } \\
\mathrm{n}=106\end{array}$} & & & \\
\hline & $\begin{array}{l}\text { Not at } \\
\text { al1 }\end{array}$ & Partly & Fully & $\begin{array}{l}\text { Not at } \\
\text { al1 }\end{array}$ & Partly & Fully \\
\hline $\begin{array}{l}\text { Organisational planning } \\
\text { and job design }\end{array}$ & 19,8 & 42,5 & 37,7 & & & \\
\hline $\begin{array}{l}\text { Job enrichment and/or } \\
\text { job enlargement }\end{array}$ & 49,1 & 37,7 & 13,2 & & & \\
\hline Integrated personnel systems & 38,7 & 37,7 & 23,6 & & & \\
\hline $\begin{array}{l}\text { Assessment centres for the } \\
\text { purpose of : selection }\end{array}$ & 64,2 & 19,8 & 16,0 & & & \\
\hline : training & 63,2 & 21,7 & 15,1 & & & \\
\hline : career planning & 76,4 & 17,0 & 6,6 & & & \\
\hline
\end{tabular}

* $\quad x^{2}$ Significant at $1 \%$ leve 1

** $x^{2}$ Significant at 5\% leve1 


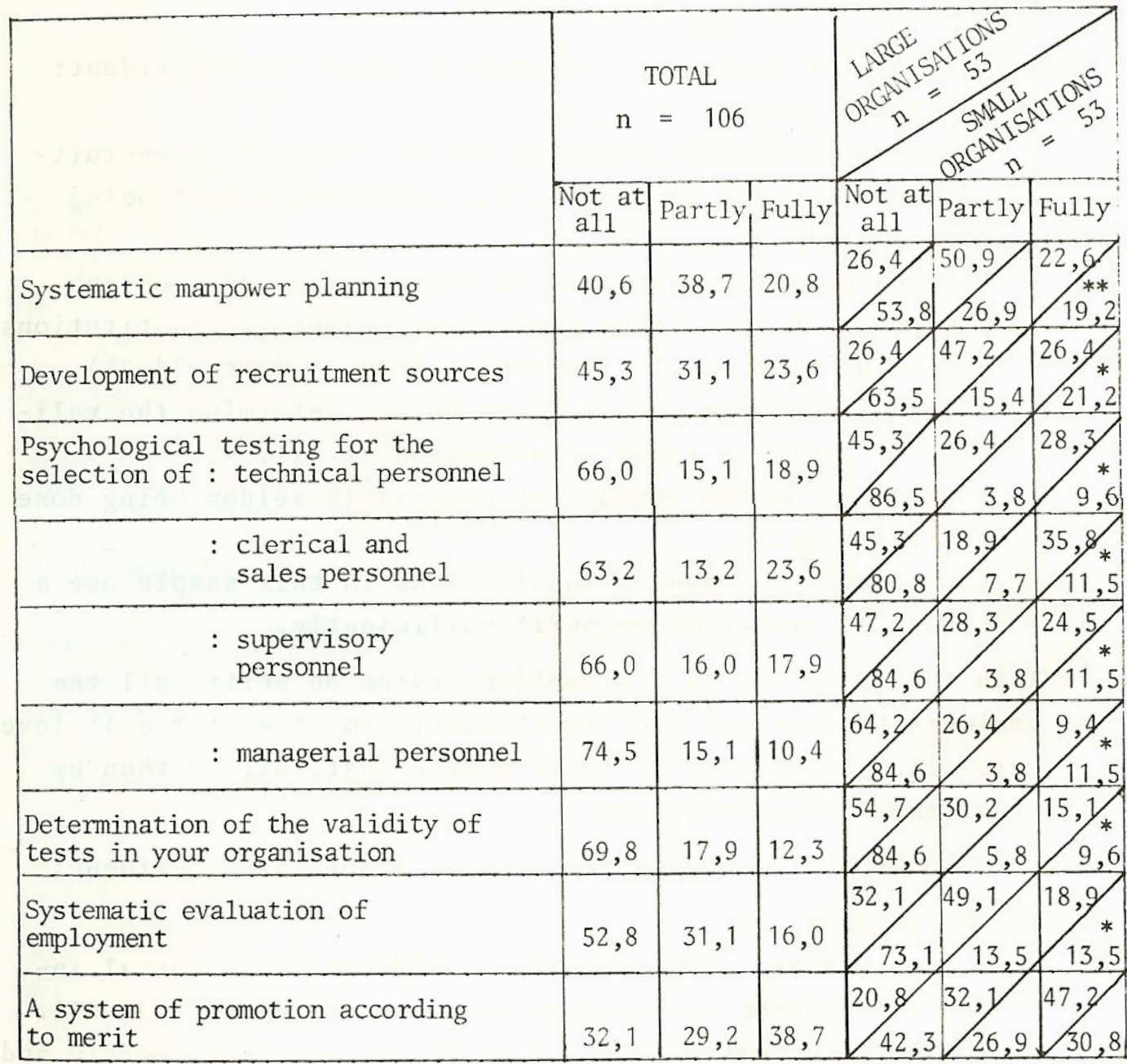

* $x^{2}$ Significant at $1 \%$ level $\quad * * x^{2}$ Significant at $5 \%$ level

- With the exception of assessment centres for selection purposes, all the personnel practices are significantly (mostly at the $1 \%$ level) more often being used by large public institutions than by their smaller counterparts.

From Table 2(b) the following are amongst other things evident:

- In the total sample

- $\quad$ systematic manpower planning and development of recruitment sources are in most public institutions not being used at all.

- $\quad$ psychological testing for the selection of various job groups is in very large percentages of public institutions not being used at all (it ranges from $63,2 \%$ to 
$74,5 \%$ ). Almost $70 \%$ of the institutions do not determine the validity of tests in their organisation at all.

- $\quad$ evaluation of the employment process is seldom being done sufficiently.

- the majority of public institutions in this sample use a system of promotion on merit sufficiently.

- With the exception of a promotion system on merit, all the employment practices are significantly (mostly at the $1 \%$ level) more often being used by large public institutions than by their smaller counterparts.

From Table 2(c) the following are amongst other things evident:

- $\quad$ In the total sample

- $\quad$ a separate training division or officer and a formal induction program are in most cases not being used at all.

- $\quad$ training to perform their present job more efficiently and development with a view to promotion to higher level jobs are in most cases only partly done.

- training in specific skills such as dealing with Black employees, communication skills and human relations is in most cases not being done at all.

- $\quad$ the start and finish of the training process viz. evaluation of training results are also in most cases not being done at all.

- $\quad$ career planning for employees is very seldom being sufficiently done.

- In large public institutions all these training practices are significantly (mostly at the $1 \%$ level) more often being used than in their smaller counterparts.

From Table 2 (d) the following are amongst other things evident:

- $\quad$ In the total sample

- all the compensation practices, with the exception of salary increases on merit and a cafeteria approach to salaries appear to be sufficiently used in this sample.

- $\quad$ a cafeteria approach to salaries/wages is in a very large percentage of cases not being used at all.

- $\quad$ In large public institutions only a salary structure and salary surveys are significantly (at the $5 \%$ level) more often being used than by their smaller counterparts. 
TABLE 2(c)

EXTENT OF USAGE OF CERTAIN TRAINING AND DEVELOPMENT, PRACTICES

(Percentages)

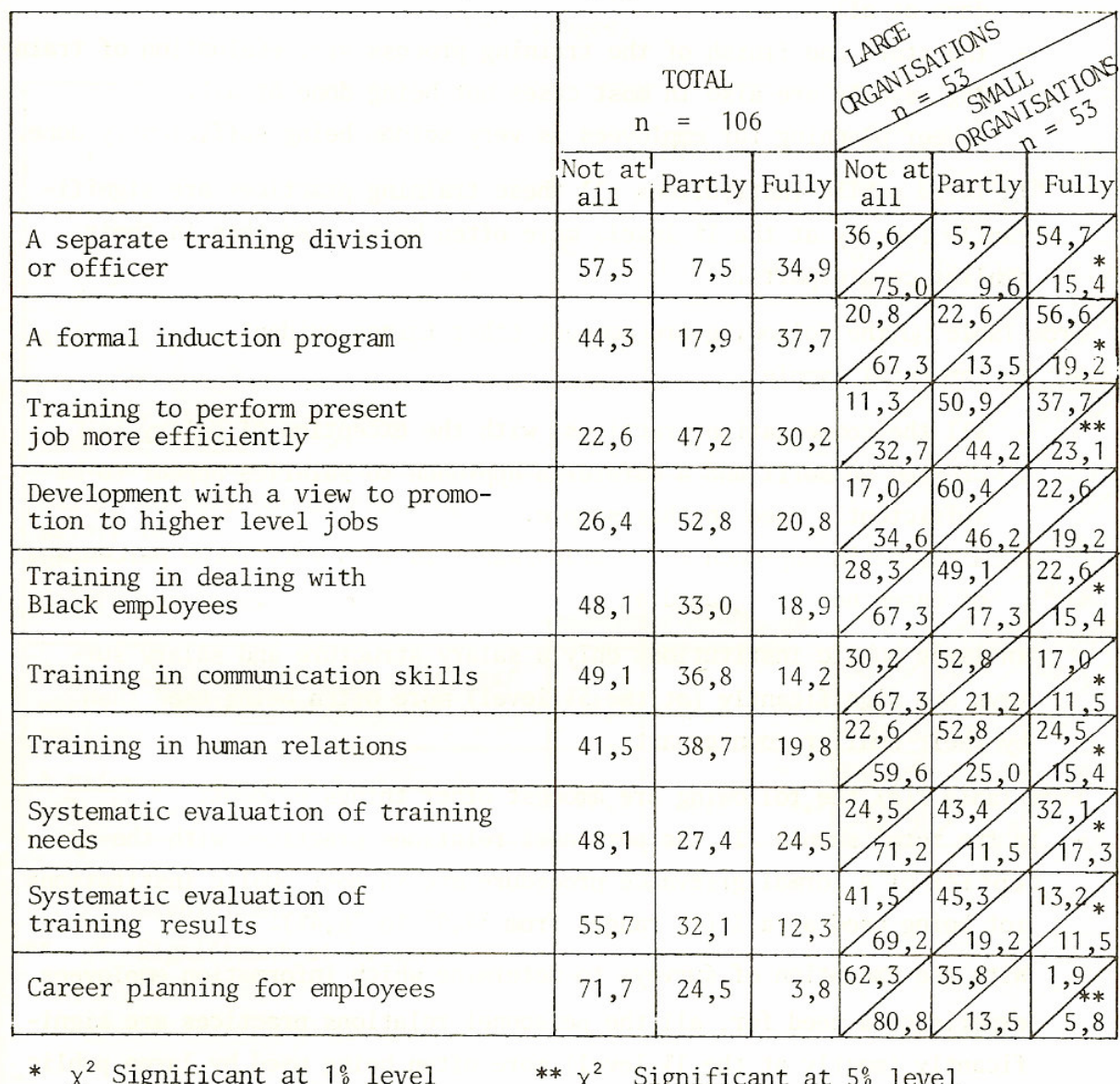

TABLE 2(d)

EXTENT OF USAGE OF CERTAIN COMPENSATION PRACTICES

(Percentages)

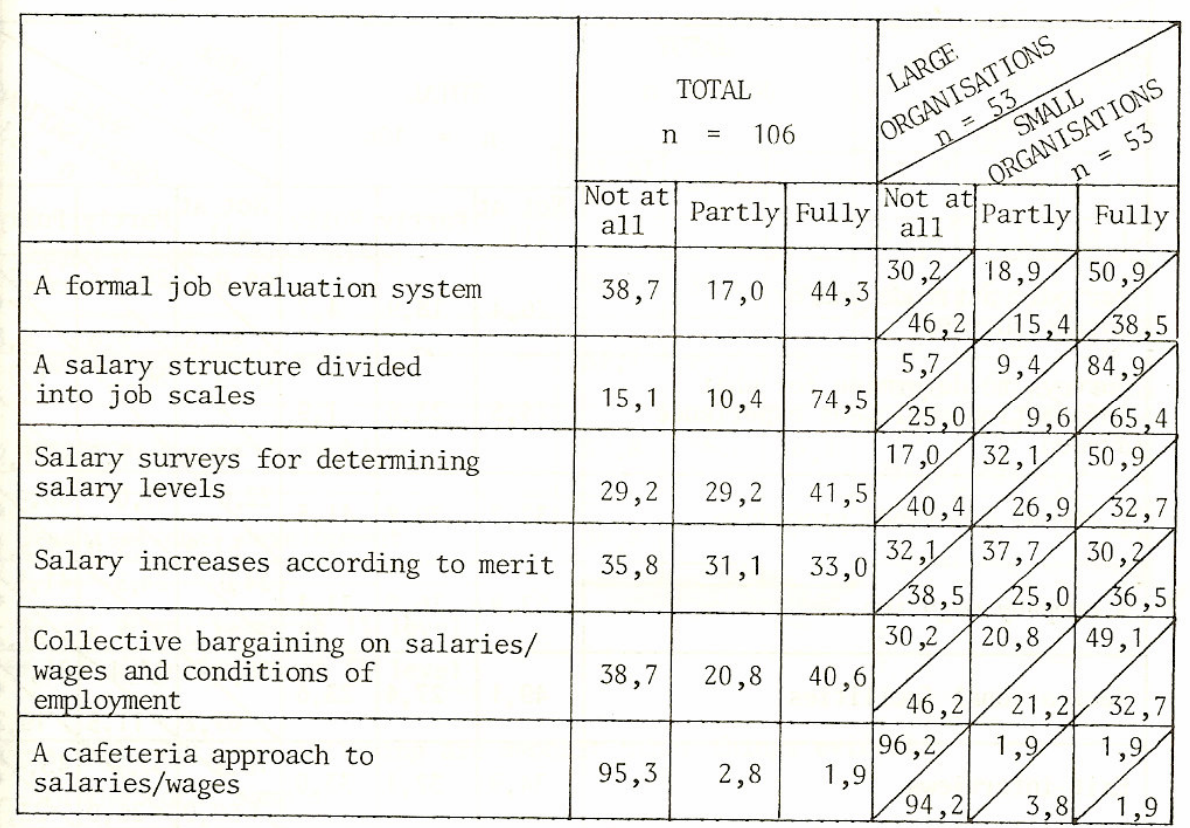

* $\chi^{2}$ Significant at $1 \%$ leve 1

** $\chi^{2}$ Significant at 5\% leve1 
From Table 2(e) the following are amongst other things evident:

- In the total sample all the personnel relations practices with the exception of a formal grievance procedure are in most public institutions not being used at all (it ranges from $34,9 \%$ to $76,4 \%)$.

- With the exception of surveys to determine which information employees experience a need for, all the personnel relations practices are significantly (mostly at the $1 \%$ level) more often being used by large public institutions than by their smaller counterparts.

TABLE $2(e)$

EXTENT OF USAGE OF CERTAIN PERSONNEL RELATIONS PRACTICES

(Percentages)

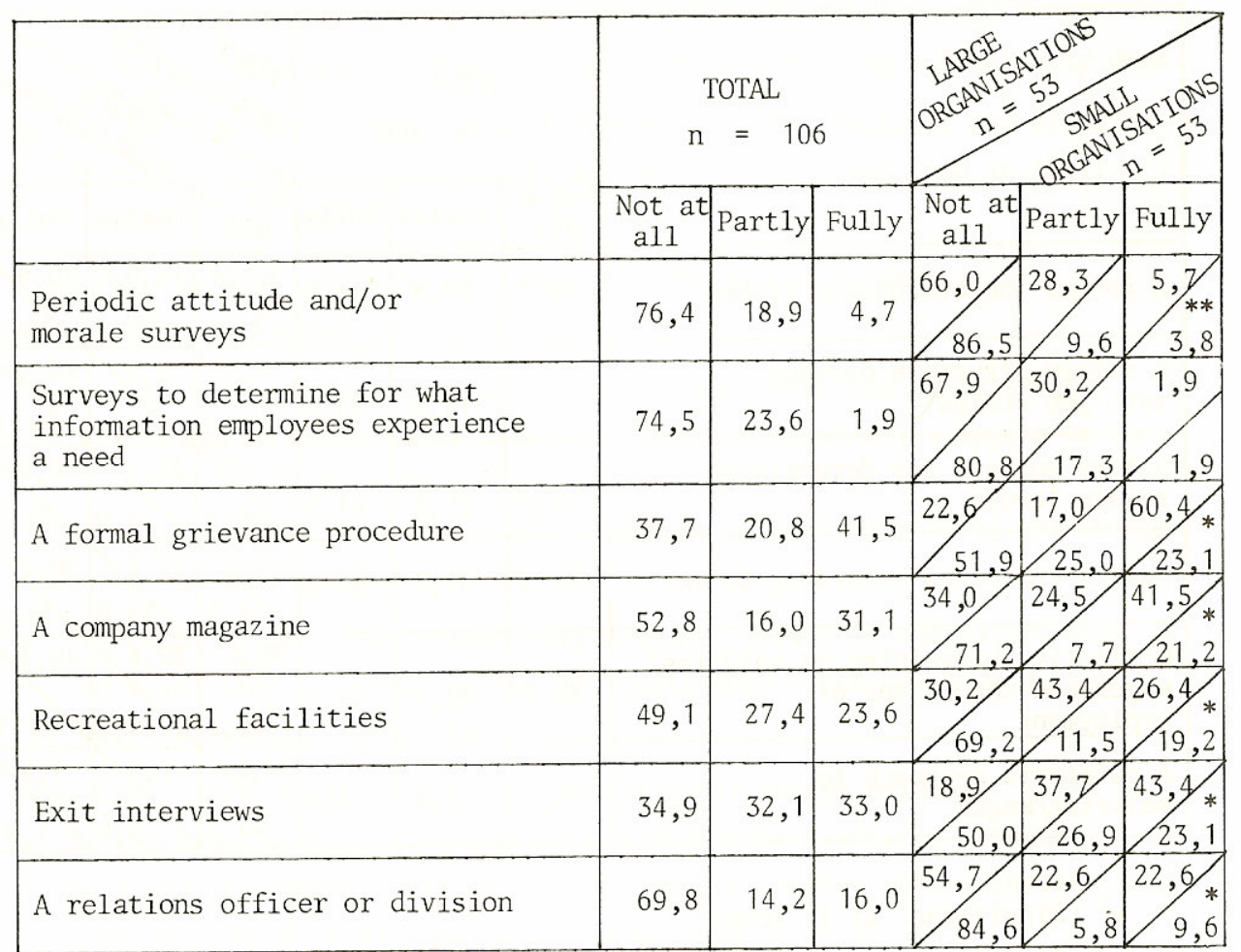

* $x^{2}$ Significant at $1 \%$ leve 1

** $x^{2}$ Significant at 5\% level 
TABLE 2(f)

EXTENT OF USAGE OF CERTAIN CONTROL AND RESEARCH PRACTICES

(Percentages)

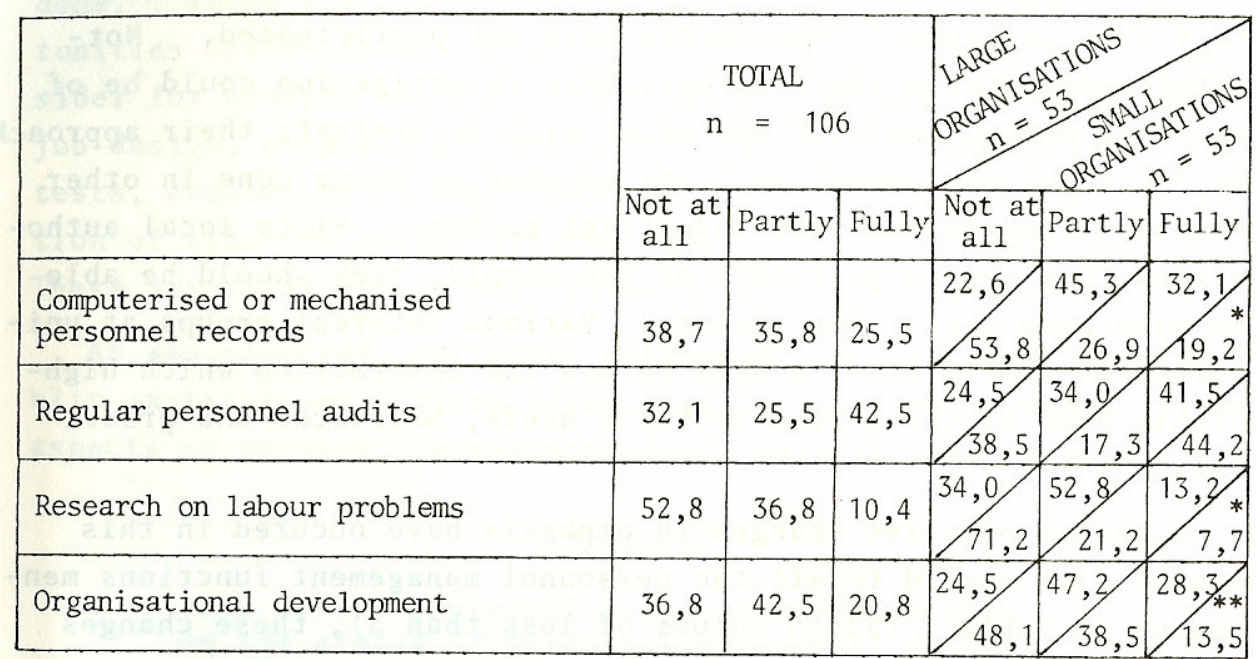

* $\chi^{2}$ Significant at $1 \%$ level

** $\chi^{2}$ Significant at $5 \%$ level

From Table 2(f) the following are amongst other things evident:

- $\quad$ In the total sample

- computerised or mechanised personnel records are being sufficiently used in only $25,5 \%$ of the cases.

- $\quad$ research on labour problems is in most cases not being conducted at all.

- $\quad$ organisational development is partly or sufficiently being used in $63,3 \%$ of the public institutions.

- $\quad$ Large public institutions are these control and research practices significantly (mostly at the $1 \%$ level) more often than their smaller counterparts.

\section{CONCLUSIONS}

This investigation has certain shortcomings e.g. the inherent limitations and shortcomings of survey research and the fact that government departments have not participated. Notwithstanding these shortcomings, this investigation could be of value to public institutions which wish to evaluate their approach to personnel management in terms of what is being done in other organisations in the same industrial sector. Since local authorities form the largest part of the sample, they should be able to make good use of the results. 
Various interest groups at universities should also be able to use the information which highlights some of the public sector's needs, practices and priorities.

Although positive changes in emphasis have occurred in this sample with regard to all the personnel management functions mentioned in Table 1 (scale values of less than 3 ), these changes are largely neutralised by the fact that the related personnel management practices are in most cases not being applied at all. Compensation in general seems to be the area where the majority of public institutions in this sample are of the opinion that they use the compensation practices mentioned, sufficiently. As far as employment and especially personnel relations are concerned, there is much room for improvement. The situation with regard to training and development is slightly better, but training in specific skills and the evaluation of the training process are in most cases not done at all.

Also in this sample in the public sector, personnel research remains the black sheep of the personnel management process.

Very little change in emphasis has occurred during the past three years with regard to personnel research. Research on labour problems is in only $10,4 \%$ of the public institutions sufficiently done. There are also within organisations many research opportunities worth investigating apart from labour problems. Consider for example job enrichment, organisational planning and job design, manpower planning, determination of the validity of tests, evaluation of employment and training results, determination of training needs, attitude and/or morale surveys and others. These practices are in most cases still not being done at all.

As was expected, personnel management in large and small public institutions differs often significantly with regard to the aspects of personnel management dealt with in this article.

\section{ABSTRACT}

Very little empirical research has been done on the status of personnel management in the public sector in South Africa. In this survey type of investigation, information was gathered on the extent and nature of change with respect to a large number of personnel management functions and the present usage of several general personnel practices as well as employment, training and development, compensation, personnel relations, control and research practices. The results of large and small public institutions were analysed separately. The results point to 
various areas of personnel management in public institutions where room for improvement exists.

\section{REFERENCES}

Cloete, J.J.N. Public enterprises in South Africa: Administrative aspects. SAIPA, 1978, 13, 126.

Department of Labour. Manpower Survey no. 13. Pretoria. Department of Labour, 1979.

Verster, R. Personnel Management in Public Institutions with special reference to Municipalities. Bloemfontein, Personnel Research Division, 1980. 